\title{
Impact of different thin layer drying temperatures on the drying time and quality of butterfly pea flowers
}

\author{
1,"*Thuy, N.M., ${ }^{2}$ Minh, V.Q., ${ }^{1}$ Ben, T.C., ${ }^{1,3,4}$ Ha, H.T.N. and ${ }^{1}$ Tai, N.V. \\ ${ }^{1}$ College of Agriculture, Can Tho University, Can Tho city, Vietnam \\ ${ }^{2}$ College of Environment and Natural Resources, Can Tho University, Can Tho city, Vietnam \\ ${ }^{3}$ Faculty of Agriculture and Natural Resources, An Giang University, No. 18, Ung Van Khiem Street, Dong \\ Xuyen Ward, Long Xuyen City, An Giang Province, Vietnam \\ ${ }^{4}$ Vietnam National University Ho Chi Minh City, Linh Trung Ward, Thu Duc District, Ho Chi Minh City,
} Vietnam

\section{Article history:}

Received: 14 May 2021

Received in revised form: 29

June 2021

Accepted: 5 September 2021

Available Online: 19

December 2021

Keywords:

Thin layer drying,

Modelling,

Butterfly pea flower,

Moisture ratio,

Diffusion coefficient

DOI:

https://doi.org/10.26656/fr.2017.5(6).328

\begin{abstract}
With attractive flower colours ranging from dark green to purple, Butterfly pea (Clitoria ternatea L.) is grown year-round in Vietnam. The purpose of this study is to determine the effect of air temperature on drying time and antioxidant compounds of Butterfly pea flowers, fitting the drying curves and testing the goodness of fit. In this study, air drying characteristics of the Butterfly pea flowers were determined using drying air temperature from $55^{\circ} \mathrm{C}$ to $70^{\circ} \mathrm{C}$ at a constant air velocity of $1 \mathrm{~m} / \mathrm{s}$. The data of experimental moisture loss were fitted to selected seven thin-layer drying models. The effect of drying conditions on the anthocyanin and total phenolic compound changes of Butterfly pea flower were compared. The effect of temperature on the diffusivity was described using the Arrhenius equation with an activation energy of $71.63 \mathrm{~kJ} \cdot \mathrm{mol}^{-1}$. At increasing temperature, the effective moisture diffusivity values ranged from $2.39 \times 10^{-12}$ and $7.76 \times 10^{-12} \mathrm{~m}^{2} \mathrm{~s}^{-1}$. The mathematical models were compared according to the three statistical parameters such as the coefficient of determination $\left(\mathrm{R}^{2}\right)$, reduced chi-square $\left(\chi^{2}\right)$ and root mean square error (RMSE) between the observed and predicted moisture ratios. The highest value of $\mathrm{R}^{2}$ $(99.8 \%)$ and the lowest values of $\chi^{2}(0.0004)$ and RMSE (0.0178) were observed for drying air temperature of $70^{\circ} \mathrm{C}$. Among the seven mathematical models tested with experimental data, the Page model could sufficiently be described the drying characteristics of the Butterfly pea flower.
\end{abstract}

\section{Introduction}

Natural colourings are extracted from vegetables, fruits, and tubers, which are available in nature. They do not only offer attractive appearances, but they have also been recognized to increase the nutritional value of the foods. In particular, butterfly pea species (Clitoria ternatea L.) possesses beautiful flowers with dark blue to purple petals that can bloom almost year-round in Vietnam. Recent concerns about the use of synthetic food colours and their effects on human health have increased, therefore, natural colourants such as butterfly pea flowers extract have become alternatives commonly in food processing. It has the potential to be used as a natural food colourant in cooking, baking and beverages (Bhowmik et al., 2010) as well as in traditional medicine (Mehmood et al., 2019). The butterfly pea flowers mostly contain alkaloids, flavonoids, taraxerols, taraxerones, triterpenoids and anthocyanins as active chemicals that bring about its biological effects (Kosai et al., 2015). Delphinidin has a higher antioxidant activity compared with some other anthocyanidins (Marpaung et al., 2013). Its extracts possess a wide range of pharmacological activities including antibacterial, antidiabetic, antidiarrheal, antifungal, anthelmintic, antiinflammatory, antimicrobial, antioxidant, antidepressant, and antipyretic activities, hypolipidemia, immunomodulatory, and wound healing (Kosai et al., 2015).

Drying is one of the methods that is widely used to preserve fruits and vegetables, in which thin-layer drying is a commonly used method for determining the drying kinetics of fruits and vegetables. Drying significantly reduces volume and weight, minimize packaging, storage and transport costs. It allowed the dried product to be 
stored easily in ambient conditions. Thus, the selection of the most suitable thin-layer drying model is also a very important tool in describing the drying behaviour of fresh fruits, vegetables and edible flowers. It was observed that butterfly pea flowers are grown year-round but they are highly perishable and therefore require careful treatment in order to preserve the bioactive compounds, especially total polyphenol and anthocyanins. Numerous experimental studies and mathematical models on the drying characteristics of various fruits and vegetables have been carried out, such as papaya (Lemus-Mondaca et al., 2013), carrot (Kaya et al., 2009), tomato (Purkayastha et al., 2011), garlic slices (Madamba et al., 1996). These mathematical models have been proposed to describe drying characteristics. However, there are still limited studies has been done on the drying of butterfly pea flowers. This study is aimed at determining the effect of different air temperatures on the drying time of butterfly pea flowers, fitting the drying curves with proposed mathematical models and testing the goodness of fit. Calculation of effective diffusivity and activation energy for the dried butterfly pea flower and analysing their properties after the drying process was done.

\section{Materials and methods}

\subsection{Raw material}

Butterfly pea flowers were grown in Vietnam. After manual pickling, approximately 100 to $200 \mathrm{~g}$ of the butterfly pea flower was subjected to drying at different temperatures.

\subsection{Drying procedure}

Four different temperatures $\left(55,60,65\right.$ and $\left.70^{\circ} \mathrm{C}\right)$ were applied and the oven dryer (Model SIBATA SD60 , Japan) was operated at an air velocity of $1.0 \mathrm{~m} / \mathrm{s}$. The change of sample weight was recorded by a digital balance (Ohaus, SR series, America, $d=0.001$ ) at a halfhourly interval during the drying process. The sample was dried until equilibrium was reached.

\subsection{Determination of total anthocyanin content (TAC)}

The TAC was determined by the $\mathrm{pH}$ differential method, its content was expressed as cyanidin-3glucoside equivalents as in the following equation (Maran et al., 2015) (Equation 1).

Anthocyanin content $(\mathrm{mg} / \mathrm{L})=\frac{\mathrm{A} \times \mathrm{MW} \times \mathrm{DF} \times \mathrm{V} \times 1000}{\mathrm{a} \times \mathrm{l} \times \mathrm{m}}$

Where $\mathrm{A}$ is the absorbance, MW is the molecular weight of cyanidin-3-glucoside $(449.2 \mathrm{~g} / \mathrm{mol})$, DF is the dilution factor, $\mathrm{V}$ is the solvent volume $(\mathrm{mL})$, $\mathrm{a}$ is the molar absorptivity $\left(26,900 \mathrm{~L} \cdot \mathrm{mol}^{-1} \cdot \mathrm{cm}^{-1}\right)$, and 1 is the cell path length $(1 \mathrm{~cm})$.

\subsection{Determination of total phenolic compound (TPC)}

The TPC was determined based on the method by Wong et al. (2006) with total content was quantified using the standard curve of gallic acid as a standard phenolic compound ( 0.2 to $1 \mathrm{mg} / \mathrm{mL})$, which was dissolved in deionised water and expressed as mg gallic acid equivalent (GAE) per gram plant material.

\subsection{Calculation of drying rate}

The drying characteristic of butterfly pea flower was examined using the drying curves and the instantaneous drying rate, DR (g water/g dry matter per min) and it was calculated as Equation 2.

$D R=\frac{\left(M_{t+d t}-M_{t}\right)}{d t}$

Where $\mathrm{M}_{\mathrm{t}+\mathrm{dt}}$ and $\mathrm{M}_{\mathrm{t}}$ are moisture contents ( $\mathrm{g}$ water/g dry matter) at time $(t+d t)$ and time $t$, respectively.

\subsection{Mathematical modelling}

In order to evaluate the characteristics of the drying process, modelling the drying process is very important. In this study, the drying curves obtained from the experiments were fitted into seven mathematical models that are commonly used for describing the thin layer drying behaviour. These were adjusted to the data from the drying process of the butterfly pea flowers, as shown in Table 1.

In order to obtain the best mathematical model, the moisture content data at different temperatures were converted to Moisture Ratio (MR) that presents the dimensionless moisture ratio using Equation 3.

$\mathrm{MR}=\frac{M_{t}-M_{e}}{M_{o}-M_{e}}$

Where $\mathrm{M}$ is the instantaneous moisture content ( $\mathrm{kg}$ water $\mathrm{kg}^{-1}$ dry matter) of the product, $\mathrm{M}_{\mathrm{o}}$ is the initial moisture content of the product and $\mathrm{M}_{\mathrm{e}}$ is the equilibrium moisture content. The values of $\mathrm{M}_{\mathrm{e}}$ are relatively negligible compared with $\mathrm{M}$ and $\mathrm{M}_{\mathrm{o}}$ for a long drying time. Thus Equation 3 has been simplified to Equation 4 (Toğrul and Pehlivan, 2004).

$\mathrm{MR}=\frac{M_{t}}{M_{o}}$

Regression analyses for determining the most suitable model for drying thin layer butterfly pea flower with different temperatures was carried out using the conventional statistical calculations namely the correlation coefficient $\left(\mathrm{R}^{2}\right)$, chi-square $\left(\chi^{2}\right)$ and root mean square error (RMSE). The highest values of $\mathrm{R}^{2}$ and the lowest values of $\chi^{2}$ and RMSE represent the best fitness with experimental data and mathematical models (Akpinar et al., 2003). These statistical values can be 
Table 1. Mathematical models used to predict the drying of agricultural products

\begin{tabular}{cllc}
\hline No. & \multicolumn{1}{c}{ Models } & \multicolumn{1}{c}{ Equation } & References \\
\hline 1 & Henderson and Pabis & $\mathrm{MR}=\mathrm{a} \cdot \exp (-\mathrm{kt})$ & Rosa et al. $(2015)$ \\
2 & Modified Henderson and Pabis & $\mathrm{MR}=\mathrm{a} \cdot \exp (-\mathrm{kt})+\mathrm{b} \cdot \exp (-\mathrm{gt})+\mathrm{c} . \exp (-\mathrm{ht})$ & Akpinar and Bicer $(2008)$ \\
3 & Logarithmic & $\mathrm{MR}=\mathrm{a} \cdot \exp (-\mathrm{kt})+\mathrm{c}$ & Akpinar and Bicer $(2008)$ \\
4 & Newton & $\mathrm{MR}=\exp (-\mathrm{kt})$ & Sobukola et al. $(2007)$ \\
5 & Page & $\mathrm{MR}=\exp \left(-\mathrm{k}\left(\mathrm{t}^{\mathrm{n}}\right)\right)$ & Akpinar and Bicer $(2008)$ \\
6 & Two-term & $\mathrm{MR}=\mathrm{a} \cdot \exp (-\mathrm{kt})+\mathrm{b} \cdot \exp \left(-\mathrm{k}_{\mathrm{o}} \mathrm{t}\right)$ & Sobukola et al. $(2007)$ \\
7 & Two-term exponential & $\mathrm{MR}=\mathrm{a} \cdot \exp (-\mathrm{kt})+(1-\mathrm{a}) \exp (-\mathrm{kat})$ & Sobukola et al. $(2007)$ \\
\hline
\end{tabular}

Where $\mathrm{t}$ is drying time (hrs); $\mathrm{a}, \mathrm{b}, \mathrm{c}, \mathrm{g}, \mathrm{h}, \mathrm{n}, \mathrm{k}, \mathrm{k}_{\mathrm{o}}$ are the model constants.

calculated using Equations 5, 6 and 7 (Akpinar, 2010).

$R^{2}=\frac{\sum_{i=1}^{N}\left(M R_{i}-M R_{\text {pre }, i}\right) \cdot \sum_{i=1}^{N}\left(M R_{i}-M R_{\text {exp }, i}\right)}{\sqrt{\left[\sum_{i=1}^{N}\left(M R_{i}-M R_{\text {pre }, i}\right)^{2}\right] \cdot\left[\sum_{i=1}^{N}\left(M R_{i}-M R_{\text {exp }, i}\right)^{2}\right]}}$

$\chi^{2}=\frac{\sum_{i=1}^{N}\left(\mathrm{MR}_{\exp , i}-\mathrm{MR}_{\mathrm{pre}, i}\right)^{2}}{N-z}$

$\mathrm{RMSE}=\left[\frac{1}{N} \sum_{i=1}^{N}\left(\mathrm{MR}_{\mathrm{pre}, i}-\mathrm{MR}_{\exp , i}\right)^{2}\right]^{1 / 2}$

Where $M R_{\text {exp,i }}$ is the $i^{\text {th }}$ experimentally observed moisture ratio, $\mathrm{MR}_{\text {pre, } \mathrm{i}}$ is the $\mathrm{i}^{\text {th }}$ predicted moisture ratio, $\mathrm{N}$ is the number of observations and $\mathrm{z}$ is the number constants.

\subsection{Calculation of the effective moisture diffusivity and activation energy}

The drying characteristics of various foods are well described by using Fick's diffusion equation (John et al., 2014). In the case of thin-layer drying, assuming onedimensional moisture movement, insignificant shrinkage, constant diffusivity, uniform initial moisture distribution and negligible external resistance (Thorat et al., 2012), a form of the equation given by Crank (1979) can be developed (Equation 8).

MR $=\frac{8}{\pi^{2}} \sum_{n=0}^{\infty} \frac{1}{(2 n+1)^{2}} \exp \left(-(2 n+1) \pi^{2} \frac{D_{\text {eff }} t}{4 L^{2}}\right)$

Where $D_{\text {eff }}$ is the effective diffusivity $\left(\mathrm{m}^{2} / \mathrm{s}\right), t$ is drying time (s), $\mathrm{n}$ is a positive integer and $\mathrm{L}$ is the haft thickness of the slab (m).

The linear solution of the equation is obtained by assuming that only the first term in the series equation is significant $(\mathrm{n}=0)$ for long drying times. Then Equation 9 is obtained by taking the natural logarithm of both sides (Akgun and Doymaz, 2005).

$\ln (\mathrm{MR})=\ln \left(\frac{8}{\pi^{2}}\right)-\left(\frac{\pi^{2}}{4 L^{2}} D_{\text {eff }} t\right)$

The diffusion coefficients can be determined by plotting experimental drying data in terms of $\ln (\mathrm{MR})$ versus drying time $(\mathrm{t})$ because the plot gives a straight line with a slope as Equation 10 (Zarein et al., 2015).

Slope $=\frac{\pi^{2} D_{\text {eff }}}{4 L^{2}}$

The activation energy is calculated using the
Arrhenius equation (Equation 11) which expresses the dependence of the effective diffusion coefficient on drying air temperature (Sanjuán et al., 2003).

$D_{\text {eff }}=D_{o} \exp \left(-\frac{E_{a}}{R T}\right)$

Where $D_{o}$ is the diffusion coefficient corresponding to infinite temperature $\left(\mathrm{m}^{2} / \mathrm{s}\right), E_{a}$ is the activation energy $(\mathrm{kJ} / \mathrm{mol}), \mathrm{R}$ is the universal gas constant $(8.314 \mathrm{~J} / \mathrm{mol} \mathrm{K})$ and $\mathrm{T}$ is the absolute drying air temperature $\left({ }^{\circ} \mathrm{K}\right)$.

\section{Results and discussion}

\subsection{Drying kinetics of dried butterfly pea flowers}

The effect of temperature used for the thin layer drying process of butterfly pea flower was remarkable with moisture ratios that have decreased continuously in increasing temperature and time (Figure 1). The final moisture content of the butterfly pea flower reached 6 to $8 \%$ (DW) after 11, 7.5, 6 and $4 \mathrm{hrs,} \mathrm{respectively} \mathrm{at}$ drying temperatures of 55, 60, 65 and $70^{\circ} \mathrm{C}$. The drying rate is higher when the temperature is increased (Figure 2 and Figure 3). As a result, the time taken to reach the final moisture content is reduced. It was also observed that there is no constant rate drying period in the drying of butterfly pea flower, indicating that diffusion is the main physical mechanism governing moisture migration in the flowers. Similar results were obtained in the study of broccoli (Doymaz, 2014) and okra (Wankhade et al., 2013).

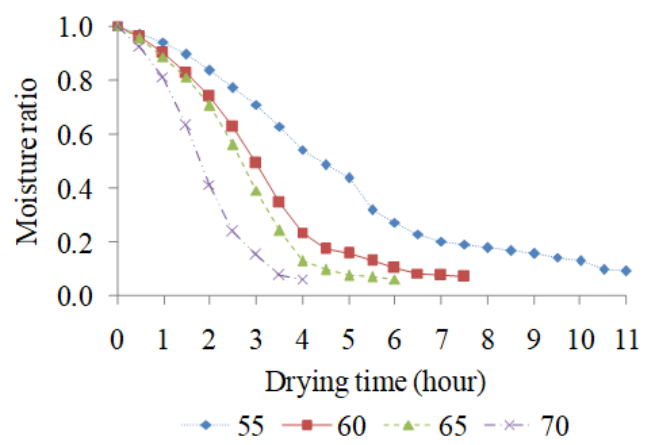

Figure 1. Moisture ratio variation as a function of drying time at different temperatures

\subsection{Mathematical modelling}

The moisture content data on different experiments were 


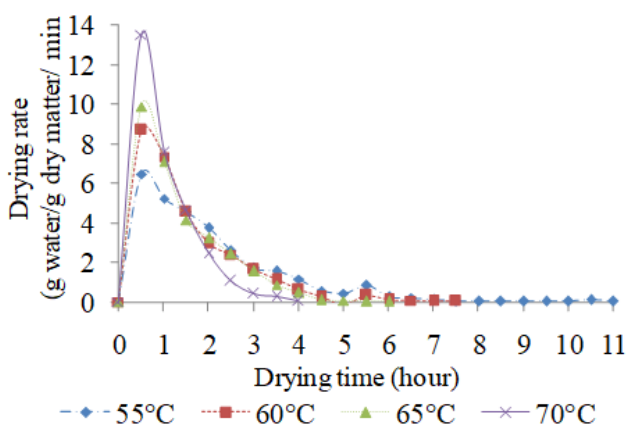

Figure 2. Drying rate of Butterfly pea flower versus drying time

converted to a more useful moisture ratio expression, and curve fitting computations with drying time were performed with the seven drying models. The results of the statistical analyses undertaken on these models for drying are given in Table 2. The models were evaluated based on Root Mean Square Error (RMSE), coefficient of determination $\left(R^{2}\right)$ and Chi-square $\left(\chi^{2}\right)$. All equations gave consistently high $R^{2}$ values in the range of 0.88 to 0.99 . This indicates that all equations could satisfactorily describe the thin layer drying rates of butterfly pea flowers with RMSE ranging from 0.0178 to 0.1658 and Chi-square ranged from 0.0004 to 0.0825 .

Among seven thin layer drying models, the Page model obtained the highest $R^{2}$ values of $0.9897,0.9874$, 0.9925 and 0.998 at $55^{\circ} \mathrm{C}, 60^{\circ} \mathrm{C}, 65^{\circ} \mathrm{C}$ and $70^{\circ} \mathrm{C}$, respectively. Similarly, the lowest RMSE values were obtained in the Page model over the specified temperature range. Thus, this model is assumed to present the thin layer drying behaviour of the butterfly pea flowers. In a thin layer drying study of persimmon slices, Doymaz (2012) also reported that the suitability of the Page model to fit the experimental drying data of persimmon slices in comparison with other empirical models at 50,60 and $70^{\circ} \mathrm{C}$.

From the results obtained, it could be seen that butterfly pea flowers can best be dried at 55 to $70^{\circ} \mathrm{C}$. Comparisons of the predicted values of the Page model with the experimental data are shown in Figure 4 and the Page model displays a good fit to the experimental values. In all temperatures studied, a satisfactory correlation between the predicted MR and the

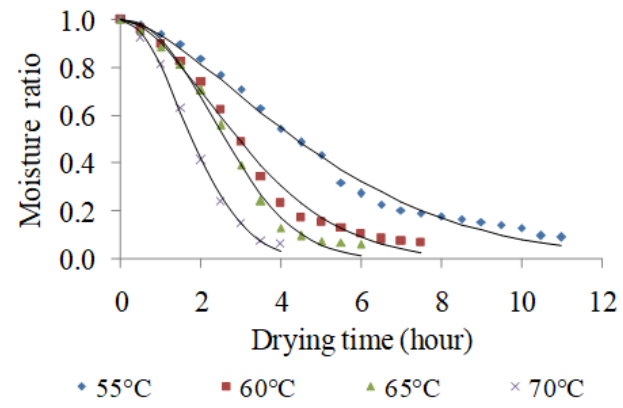

Figure 4. Comparison of experimental data and predicted moisture ratio using Page model for Butterfly pea flowers

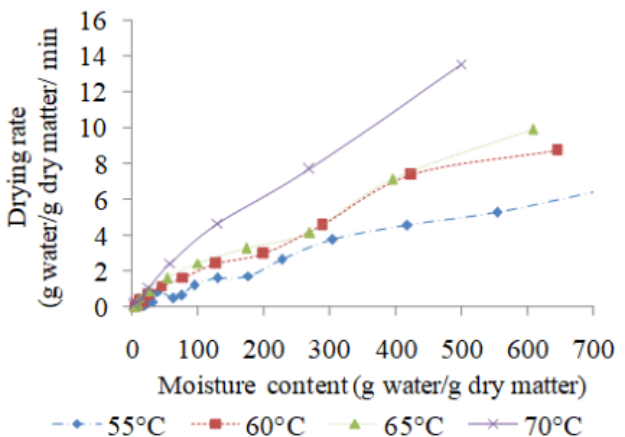

Figure 3. Drying rate of Butterfly pea flower versus moisture content

experimentally determined MR was found with an $R^{2}$ value of 0.99 (Figure 5).

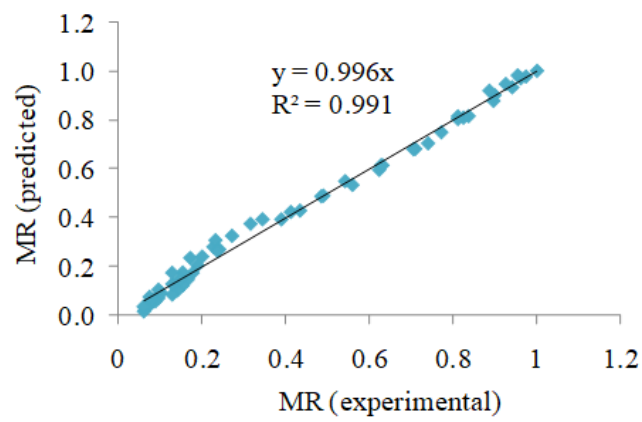

Figure 5. Correlation between the experimentally determined MR values and the MR values estimated for Butterfly pea flower using the Page model

\subsection{The moisture diffusivity and activation energy}

The effective diffusivity values of dried butterfly pea flowers at 55 to $70^{\circ} \mathrm{C}$ were varied in the range of $2.392 \times$ $10^{-12}$ to $7.756 \times 10^{-12} \mathrm{~m}^{2} / \mathrm{s}$. It was observed that the values of $D_{\text {eff }}$ increased significantly within creasing temperature. Drying at $70^{\circ} \mathrm{C}$ gave the highest $\mathrm{D}_{\text {eff }}$ values. These values are consistent with the estimated $\mathrm{D}_{\text {eff }}$ values for the Vernonia amygdalina leaves (Alara et al., 2019), the effective diffusivities for the three air temperatures ranged $\left(40,50\right.$ and $\left.60^{\circ} \mathrm{C}\right)$ from $4.55 \times 10^{-12}$ to $5.48 \times 10^{-12} \mathrm{~m}^{2} / \mathrm{s}$. To obtain the effect of temperature on the effective diffusivity, the values of $\ln \left(D_{\text {eff }}\right)$ versus $1 / T$ $(1 / \mathrm{K})$, are plotted as presented in Figure 6 . The plot was found to be a straight line over the temperature range investigated, indicating Arrhenius dependency. The activation energy was calculated from the slope of the straight line and was found to be $71.63 \mathrm{~kJ} / \mathrm{mol}$.

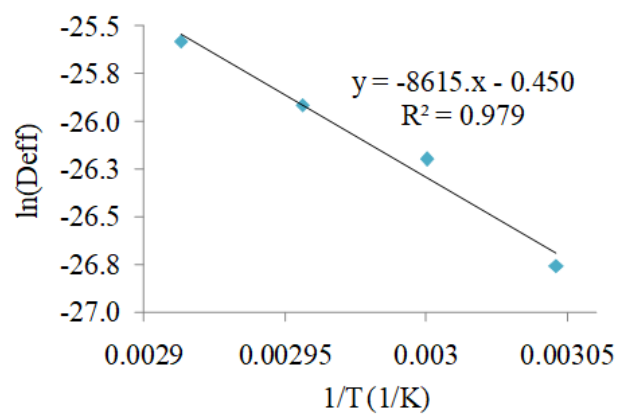

Figure 6. Influence of air temperature on the effective diffusivity 
Table 2. Modelling the thin-layer drying process of Butterfly pea flowers at different temperatures

\begin{tabular}{|c|c|c|c|c|c|}
\hline Model & Temperature $\left({ }^{\circ} \mathrm{C}\right)$ & Model constants & RSME & $\mathrm{R}^{2}(\%)$ & $\chi^{2}$ \\
\hline \multicolumn{6}{|c|}{ Henderson and Pabis } \\
\hline & 55 & $\mathrm{a}=1.1385 ; \mathrm{k}=0.2206$ & 0.0630 & 96.37 & 0.0043 \\
\hline & 60 & $\mathrm{a}=1.4162 ; \mathrm{k}=0.3171$ & 0.0849 & 94.46 & 0.0082 \\
\hline & 65 & $\mathrm{a}=1.1589 ; \mathrm{k}=0.3741$ & 0.1157 & 91.13 & 0.0158 \\
\hline & 70 & $\mathrm{a}=1.1253 ; \mathrm{k}=0.5208$ & 0.1085 & 92.58 & 0.0151 \\
\hline \multicolumn{6}{|c|}{ Modified Henderson and Pabis } \\
\hline & 55 & $\begin{array}{l}\mathrm{a}=0.3795 ; \mathrm{k}=0.2057 ; \mathrm{b}=0.3795 \\
\mathrm{~g}=0.2057 ; \mathrm{c}=0.3795 ; \mathrm{h}=0.2057\end{array}$ & 0.0700 & 96.37 & 0.0066 \\
\hline & 60 & $\mathrm{a}=0.3821 ; \mathrm{k}=0.3172 ; \mathrm{b}=0.3821$ & 0.1005 & 94.46 & 0.0161 \\
\hline & 65 & $\begin{array}{c}\mathrm{g}=0.3172 ; \mathrm{c}=0.3821 ; \mathrm{h}=0.3169 \\
\mathrm{a}=0.3863 ; \mathrm{k}=0.3741 ; \mathrm{b}=0.3863 ; \\
\mathrm{g}=0.3741 ; \mathrm{c}=0.3863 ; \mathrm{h}=0.3741\end{array}$ & 0.1450 & 91.13 & 0.0391 \\
\hline & 70 & $\begin{array}{l}\mathrm{a}=0.3751 ; \mathrm{k}=0.5224 ; \mathrm{b}=0.3751 \\
\mathrm{~g}=0.5207 ; \mathrm{c}=0.3751 ; \mathrm{b}=0.5194\end{array}$ & 0.1658 & 92.58 & 0.0825 \\
\hline \multicolumn{6}{|c|}{ Logarithmic } \\
\hline & 55 & $\mathrm{a}=1.3600 ; \mathrm{k}=0.1336 ; \mathrm{c}=-0.2662$ & 0.0520 & 97.64 & 0.0031 \\
\hline & 60 & $\mathrm{a}=1.457 ; \mathrm{k}=0.1830 ; \mathrm{c}=-0.3616$ & 0.0826 & 95.89 & 0.0084 \\
\hline & 65 & $\mathrm{a}=2.0367 ; \mathrm{k}=0.1339 ; \mathrm{c}=-0.9457$ & 0.0826 & 95.89 & 0.0179 \\
\hline & 70 & $\mathrm{a}=2.2489 ; \mathrm{k}=0.1624 ; \mathrm{c}=-1.1825$ & 0.0700 & 97.36 & 0.0073 \\
\hline \multicolumn{6}{|l|}{ Newton } \\
\hline & 55 & $\mathrm{k}=0.1791$ & 0.0802 & 93.84 & 0.0067 \\
\hline & 60 & $\mathrm{k}=0.2764$ & 0.0996 & 91.83 & 0.0106 \\
\hline & 65 & $\mathrm{k}=0.3234$ & 0.1286 & 88.05 & 0.0179 \\
\hline & 70 & $\mathrm{k}=0.4626$ & 0.1160 & 90.31 & 0.0151 \\
\hline \multicolumn{6}{|l|}{ Page } \\
\hline & 55 & $\mathrm{k}=0.0702 ; \mathrm{n}=1.5502$ & 0.0320 & 98.97 & 0.0011 \\
\hline & 60 & $\mathrm{k}=0.1049 ; \mathrm{n}=1.749$ & 0.0380 & 98.74 & 0.0017 \\
\hline & 65 & $\mathrm{k}=0.0854 ; \mathrm{n}=2.1826$ & 0.0318 & 99.25 & 0.0012 \\
\hline & 70 & $\mathrm{k}=0.2199 ; \mathrm{n}=1.9744$ & 0.0178 & 99.80 & 0.0004 \\
\hline \multicolumn{6}{|c|}{ Two-term } \\
\hline & 55 & $\begin{array}{l}\mathrm{a}=0.5692 ; \mathrm{k}=0.2057 \\
\mathrm{~b}=0.5692 ; \mathrm{k}_{\mathrm{o}}=0.2057\end{array}$ & 0.0662 & 96.37 & 0.0053 \\
\hline & 60 & $\begin{array}{l}\mathrm{a}=0.5731 ; \mathrm{k}=0.3170 \\
\mathrm{~b}=0.5731 ; \mathrm{k}_{\mathrm{o}}=0.3172\end{array}$ & 0.0917 & 94.46 & 0.0112 \\
\hline & 65 & $\begin{array}{l}a=0.5794 ; \mathrm{k}=0.3736 \\
\mathrm{~b}=0.5794 ; \mathrm{k}_{\mathrm{o}}=0.3745\end{array}$ & 0.1279 & 91.13 & 0.0236 \\
\hline & 70 & $\begin{array}{l}a=0.5626 ; \mathrm{k}=0.5211 \\
\mathrm{~b}=0.5626 ; \mathrm{k}_{\mathrm{o}}=0.5206\end{array}$ & 0.1284 & 92.58 & 0.0297 \\
\hline \multicolumn{6}{|c|}{ Two-term exponential } \\
\hline & 55 & $\mathrm{a}=1.0342 ; \mathrm{k}=0.1786$ & 0.0821 & 93.84 & 0.0074 \\
\hline & 60 & $\mathrm{a}=1.0189 ; \mathrm{k}=0.2761$ & 0.1031 & 91.83 & 0.0121 \\
\hline & 65 & $\mathrm{a}=0.9870 ; \mathrm{k}=0.3238$ & 0.1343 & 88.05 & 0.0213 \\
\hline & 70 & $\mathrm{a}=1.0031 ; \mathrm{k}=0.4608$ & 0.1240 & 90.31 & 0.0198 \\
\hline
\end{tabular}

The values of activation energy for most agricultural food products lie within the range of $12.7-110 \mathrm{~kJ} / \mathrm{mol}$ (Akpinar et al., 2003). The $\mathrm{E}_{\mathrm{a}}$ obtained from this work is within the general range for food materials, it is found to be lower and higher with other food products reported. This value is higher than that of Andrographis paniculata drying $33.4 \mathrm{~kJ} / \mathrm{mol}$ (Hee and Chong, 2015), okra $51.267 \mathrm{~kJ} / \mathrm{mol}$ (Doymaz, 2005), Dill and parsley leave 35.05 and $43.92 \mathrm{~kJ} / \mathrm{mol}$ (Doymaz et al., 2006), Mint leaves 57.12 and $62.96 \mathrm{~kJ} / \mathrm{mol}$ (Kane et al., 2009;
Doymaz, 2006), but lower than Mint leaves $(82.93 \mathrm{~kJ} /$ mol) that was reported by Park et al. (2002), and black tea $406.028 \mathrm{~kJ} / \mathrm{mol}$ (Panchariya et al., 2002). Lower activation energy indicates lower sensitivity to air temperature.

3.4 The change of total phenolic and anthocyanin content of butterfly pea flower by drying

The total phenolic (TPC) and anthocyanin content in the butterfly pea flower remained high as drying 
temperatures increased, the highest concentration was found at drying temperatures of 65 and $70^{\circ} \mathrm{C}$ (Table 3). These results may be explained by the long exposure time in the drying process at low temperature (55 to $60^{\circ} \mathrm{C}$ ) and the enzymatic browning reaction that occurred during the drying process. However, the content of TPC and anthocyanin in dried Clitoria ternatea were lower than fresh flowers, and after drying, TPC and anthocyanin of samples were ranged from 64.24 to 65.54 $\mathrm{mg}$ GAE $/ \mathrm{g}(\mathrm{dwb})$ and $0.89 \pm 0.01$ to $1.50 \pm 0.04 \mathrm{mg} / \mathrm{g}$ flower $(\mathrm{dwb})$, respectively in comparison (as seen in Table 3). Higher drying temperatures $\left(65\right.$ to $\left.70^{\circ} \mathrm{C}\right)$ not only maintained the bioactive compounds but also improved the colour retention of dried butterfly pea flowers.

Table 3. The bioactive compounds of fresh and dried Butterfly pea flowers

\begin{tabular}{|c|c|c|}
\hline Samples & TPC (mgGAE/g dwb) & Anthocyanin (mg/g dwb) \\
\hline \multicolumn{3}{|c|}{ Fresh Butterfly pea flower } \\
\hline & $67.82 \pm 0.13$ & $2.33 \pm 0.11$ \\
\hline \multicolumn{3}{|c|}{ Dried Butterfly pea flower } \\
\hline $55^{\circ} \mathrm{C}$ & $64.24 \pm 0.09$ & $0.89 \pm 0.01$ \\
\hline $60^{\circ} \mathrm{C}$ & $64.98 \pm 0.11$ & $1.30 \pm 0.02$ \\
\hline $65^{\circ} \mathrm{C}$ & $65.46 \pm 0.10$ & $1.47 \pm 0.03$ \\
\hline $70^{\circ} \mathrm{C}$ & $65.54 \pm 0.12$ & $1.50 \pm 0.04$ \\
\hline
\end{tabular}

Values are expressed as the mean \pm standard deviation. The moisture content of fresh and dried samples were $90.05 \%$ and $6-8 \%$, respectively.

\section{Conclusion}

Thin layer drying characteristics of butterfly pea flowers were investigated at four drying temperatures. As expected, the drying process was shorter at higher drying temperatures. The experimental drying data were fitted to seven empirical mathematical models. Among them, the Page model described the best representation of the experimental drying values at all investigated temperatures $\left(55,60,65\right.$ and $\left.70^{\circ} \mathrm{C}\right)$, with the highest $R^{2}$ value and lowest RSME and $\chi^{2}$ values. Arrhenius' equation was used to evaluate the temperature dependence of the effective diffusivity for calculating activation energy. The findings of this study may be important by providing information for thin-layer drying process conditions of butterfly pea flower from an industrial purpose. The use of temperature from 60 to $70^{\circ} \mathrm{C}$ for the drying of butterfly pea flower in order to preserve its total phenolic and anthocyanin was also suggested.

\section{Conflict of interest}

The authors declare no conflict of interest.

\section{References}

Akgun, N.A. and Doymaz, I. (2005). Modelling of olive cake thin-layer drying process. Journal of Food Engineering, 68(4), 455-461. https:// doi.org/10.1016/j.jfoodeng.2004.06.023

Akpinar, E., Midilli, A. and Bicer, Y. (2003). Single layer drying behaviour of potato slices in a convective cyclone dryer and mathematical modeling. Energy Conversion and Management, 44 (10), 1689-1705. https://doi.org/10.1016/S0196-8904 (02)00171-1

Akpinar, E.K. (2010). Drying of mint leaves in a solar dryer and under open sun: modelling, performance analyses. Energy Conversion and Management, 51 (12), 2407-2418. https://doi.org/10.1016/ j.enconman.2010.05.005

Akpinar, E.K. and Bicer, Y. (2008). Mathematical modelling of thin layer drying process of long green pepper in solar dryer and under open sun. Energy Conversion and Management, 49(6), 1367-1375. https://doi.org/10.1016/j.enconman.2008.01.004

Alara, O.R., Abdurahman, N.H. and Olalere, O.A. (2019). Mathematical modelling and morphological properties of thin layer oven drying of Vernonia amygdalina leaves. Journal of the Saudi Society of Agricultural Sciences, 18(3), 309-315. https:// doi.org/10.1016/j.jssas.2017.09.003

Crank, J. (1979). The mathematics of diffusion. United Kingdom: Oxford University Press.

Doymaz, İ. (2005). Drying characteristics and kinetics of okra. Journal of Food Engineering, 69(3), 275-279. https://doi.org/10.1016/j.jfoodeng.2004.08.019

Doymaz, I. (2006). Thin-layer drying behaviour of mint leaves. Journal of Food Engineering, 74(3), 370375. https://doi.org/10.1016/j.jfoodeng.2005.03.009

Doymaz, İ. (2012). Evaluation of some thin-layer drying models of persimmon slices (Diospyros kaki L.). Energy Conversion and Management, 56, 199205. https://doi.org/10.1016/j.enconman.2011.11.027

Doymaz, I. (2014). Effect of blanching temperature and dipping time on drying time of broccoli. Food Science and Technology International, 20(2), 149157.https://doi.org/10.1177/1082013213476075

Doymaz, İ., Tugrul, N. and Pala, M. (2006). Drying characteristics of dill and parsley leaves. Journal of Food Engineering, 77(3), 559-565. https:// doi.org/10.1016/j.jfoodeng.2005.06.070

Hee, Y.Y. and Chong, G.H. (2015). Drying behaviour of Andrographis paniculata in vacuum drying. International Food Research Journal, 22(1), 393-397

John, S.G., Sangamithra, A., Veerapandian, C., Sasikala, 
S. and Sanju, V. (2014). Mathematical Modelling of the Thin Layer Drying of Banana Blossoms. Journal of Nutritional Health and Food Engineering ,1(2), 00008. https://doi.org/10.15406/jnhfe.2014.01.00008

Kane, C.E., Sid'Ahmed, M.A.O. and Kouhila, M. (2009). Evaluation of drying parameters and sorption isotherms of mint leaves (M. pulegium). Home, 12 (3), 449-470.

Kaya, A., Aydin, O. and Demirtaş, C. (2009). Experimental and theoretical analysis of drying carrots. Desalination, 237, 285-295. https:// doi.org/10.1016/j.desal.2008.01.022

Kosai, P., Sirisidthi, K., Jiraungkoorskul, K. and Jiraungkoorskul, W. (2016). Review on Ethnomedicinal uses of Memory Boosting Herb, Butterfly Pea, Clitoria ternatea. Journal of Natural Remedies, 15(2), 71-76.https://doi.org/10.18311/ jnr/2015/480

Lemus-Mondaca, R.A., Zambra, C.E., Vega-Gálvez, A. and Moraga, N.O. (2013). Coupled 3D heat and mass transfer model for numerical analysis of drying process in papaya slices. Journal of Food Engineering, 116(1), 109-117. https:// doi.org/10.1016/j.jfoodeng.2012.10.050

Madamba, P.S., Driscoll, R.H. and Buckle, K.A. (1996). The thin-layer drying characteristics of garlic slices. Journal of Food Engineering, 29(1), 7597. https://doi.org/10.1016/0260-8774(95)00062-3

Maran, J.P., Sivakumar, V., Thirugnanasambandham, K. and Sridhar, R. (2015). Extraction of natural anthocyanin and colors from pulp of jamun fruit. Journal of Food Science and Technology, 52 (6), 3617-3626. https://doi.org/10.1007/s13197-0141429-0

Marpaung, A.M., Andarwulan, N. and Prangdimurti, E. (2012). the optimization of anthocyanin pigment extraction from butterfly pea (Clitoria ternatea L.) Petal using response surface methodology. Acta Horticulturae, 1011, 205-211. https:// doi.org/10.17660/ActaHortic.2013.1011.24

Mehmood, A., Ishaq, M., Zhao, L., Yaqoob, S., Safdar, B., Nadeem, M. and Wang, C. (2019). Impact of ultrasound and conventional extraction techniques on bioactive compounds and biological activities of blue butterfly pea flower (Clitoria ternatea L.). Ultrasonics Sonochemistry, 51, 12-19. https:// doi.org/10.1016/j.ultsonch.2018.10.013

Panchariya, P.C., Popovic, D. and Sharma, A.L. (2002). Thin-layer modelling of black tea drying process. Journal of Food Engineering, 52(4), 349357. https://doi.org/10.1016/S0260-8774(01)00126-1

Park, K.J., Vohnikova, Z., and Brod, F.P.R. (2002).
Evaluation of drying parameters and desorption isotherms of garden mint leaves (Mentha crispa L.). Journal of Food Engineering, 51(3), 193199.https://doi.org/10.1016/S0260-8774(01)00055-3

Purkayastha, M.D., Nath, A., Deka, B.C. and Mahanta, C.L. (2013). Thin layer drying of tomato slices. Journal of Food Science and Technology, 50 (4), 642-653.https://doi.org/10.1007/s13197-0110397-x

Rosa, D.P., Cantú-Lozano, D., Luna-Solano, G., Polachini, T.C. and Telis-Romero, J. (2015). Mathematical modeling of orange seed drying kinetics. Ciência e Agrotecnologia, 39(3), 291-300. https://doi.org/10.1590/S1413-70542015000300011

Sanjuán, N., Lozano, M., García-Pascual, P. and Mulet, A. (2003). Dehydration kinetics of red pepper (Capsicum annuum L var Jaranda). Journal of the Science of Food and Agriculture, 83(7), 697-701. https://doi.org/10.1002/jsfa.1334

Sobukola, O.P., Dairo, O.U., Sanni, L.O., Odunewu, A.V. and Fafiolu, B.O. (2007). Thin layer drying process of some leafy vegetables under open sun. Food Science and Technology International, 13 (1), 35-40. https:// doi.org/10.1177/1082013207075953

Thorat, I.D., Mohapatra, D., Sutar, R.F., Kapdi, S.S. and Jagtap, D.D. (2012). Mathematical modeling and experimental study on thin-layer vacuum drying of ginger (Zingiber officinale R.) slices. Food and Bioprocess Technology, 5(4), 1379-1383. https:// doi.org/10.1007/s11947-010-0429-y

Toğrul, İ.T. and Pehlivan, D. (2004). Modelling of thin layer drying kinetics of some fruits under open-air sun drying process. Journal of Food Engineering, 65 (3), 413-425. https://doi.org/10.1016/ j.jfoodeng.2004.02.001

Wankhade, P.K., Sapkal, R.S. and Sapkal, V.S. (2013). Drying characteristics of okra slices on drying in hot air dryer. Procedia Engineering, 51, 371-374. https://doi.org/10.1016/j.proeng.2013.01.051

Wong, S.P., Leong, L.P. and Koh, J.H.W. (2006). Antioxidant activities of aqueous extracts of selected plants. Food Chemistry, 99(4), 775-783. https:// doi.org/10.1016/j.foodchem.2005.07.058

Zarein, M., Samadi, S.H. and Ghobadian, B. (2015). Investigation of microwave dryer effect on energy efficiency during drying of apple slices. Journal of the Saudi Society of Agricultural Sciences, 14(1), 4147.https://doi.org/10.1016/j.jssas.2013.06.002 